DOI: https://doi.org/10.24127/ajpm.v10i1.3477

\title{
PERBEDAAN KEYAKINAN MAHASISWA DAN HUBUNGANNYA DENGAN PRAKTIK PEMBELAJARAN DITINJAU DARI ADVERSITY QUOTIENT
}

\author{
Muhtarom $^{1}$ \\ ${ }^{1}$ Pendidikan Matematika, Universitas PGRI Semarang, Semarang, Indonesia \\ *Corresponding author. \\ E-mail: $\quad \underline{\text { muhtarom@upgris.ac.id }}^{\text {I) }}$
}

Received 13 January 2021; Received in revised form 09 March 2021; Accepted 30 March 2021

\begin{abstract}
Abstrak
Penelitian ini menguraikan keyakinan mahasiswa dan hubungan keyakinan dengan praktik pembelajaran matematika di kelas ditinjau dari perbedaan adversity quotient (AQ). Tiga mahasiswa yang masingmasing memiliki AQ yang berbeda yaitu climber, camper dan quitter menjadi subjek dalam penelitian ini. Subjek ini memiliki kemampuan komunikasi yang baik, lulus microteaching dan belum berpengalaman dalam pengajaran matematika di sekolah. Data penelitian dikumpulkan melalui wawancara dan observasi pembelajaran di kelas. Dua kali wawancara dan observasi pembelajaran untuk setiap subjek penelitian dilakukan untuk mendapatkan data penelitian yang kredibel. Video hasil wawancara dan video praktik pembelajaran matematika di kelas diputar berulang kali untuk meningkatkan ketekunan terhadap perolehan data penelitian. Data diberi kode, dipaparkan, ditriangulasi, dan dianalisis untuk menggambarkan keyakinan dan implementasi keyakinan dalam praktik pembelajaran. Hasil penelitian menunjukkan bahwa terdapat perbedaan keyakinan antara mahasiswa climber, camper dan quitter. Keyakinan yang dimiliki oleh masing-masing mahasiswa benar-benar diterapkan dalam praktik pembelajaran matematika di kelas. Ini menunjukkan terdapat derajat kekonsistenan yang tinggi antara keyakinan dan praktik pembelajaran yang dilaksanakan.
\end{abstract}

Kata kunci: Adversity quotient; keyakinan; praktik pembelajaran.

\begin{abstract}
This research explained prospective teacher beliefs and the relationship between beliefs and practice of learning mathematics in the classroom in terms of differences in adversity quotient (AQ). Three prospective teacher who each had different $A Q$, namely climber, camper and quitter, were the subjects in this research. This subject has good communication skills, has passed microteaching and has no experience in teaching mathematics in schools. The research data were collected through interviews and classroom observation. Two interviews and learning observations for each research subject were carried out to obtain credible research data. Videos from interviews and video practice of learning mathematics in class were played repeatedly to increase the persistence in obtaining research data. The data that had been obtained were coded, reduced, triangulated, and analyzed to describe beliefs and implementations of beliefs in learning practices. The results showed that there were differences in beliefs between climber, camper and quitter students. The beliefs held by each student are actually applied in the practice of learning mathematics in the classroom. This shows that there is a high degree of consistency between beliefs and the practice of learning carried out.
\end{abstract}

Keywords: Adversity quotient; beliefs; teaching practice.

This is an open access article under the Creative Commons Attribution 4.0 International License

\section{PENDAHULUAN}

Peranan guru

pembelajaran sangat

memegang peran penting dalam membangun keyakinan siswa terhadap matematika. Cara guru mengajar mempengaruhi keyakinan siswa terhadap matematika (Muhtarom et al., 
2018). Dijelaskan dalam Permendiknas RI No 16 tentang Standar Kualifikasi Akademik dan Kompetensi Guru (2007) bahwa rasa percaya diri disamakan dengan keyakinan merupakan sikap mental yang dimiliki guru terhadap manfaat matematika bagi siswa, dirinya, dan kehidupan sehari-hari, serta keyakinan akan kemampuan dirinya dalam pembelajaran matematika. Keyakinan guru tentang bagaimana ilmu pengetahuan dikembangkan berkaitan dengan keyakinan mereka tentang bagaimana mengajarkan ilmu dan bagaimana siswa belajar di dalam kelas (Siswono et al., 2019). Ini berarti keyakinan matematika menjadi bagian yang tak terpisahkan dari kompetensi seorang guru.

Keyakinan adalah sebuah konsep yang berhubungan dengan sikap (Muhtarom, Juniati, \& Siswono, 2017). Sikap melibatkan apa yang seseorang pikirkan, rasakan dan bagaimana berperilaku terhadap suatu objek. Perilaku tidak hanya dipengaruhi oleh apa yang orang ingin lakukan tetapi juga apa yang harus dilakukan dan konsekuensi dari perilakunya Siswono, Kohar, \& Hartono, 2017). Keyakinan menyiratkan bagian dari persepsi yang didasarkan pada asumsi, namun bagaimanapun juga keyakinan juga dapat didasarkan pada bagian yang dapat didefinisikan sebagai pengetahuan (Belbase, 2019). Sedangkan keyakinan yang didasarkan pada pengetahuan disebut sebagai nilai. Dalam bidang pendidikan, Muhtarom, Juniati, \& Siswono (2019) menjelaskan bahwa keyakinan sebagai sistem yang terintegrasi dengan pengetahuan yang mempengaruhi praktik pembelajaran. Ini menunjukkan bahwa keyakinan mencerminkan filosofi guru tentang hakikat ilmu dan cara memperolehnya, pada gilirannya mempengaruhi pengambilan keputusan dan pendekatan pembelajaran yang dilakukan oleh seorang guru.

Keyakinan dapat dikategorikan dalam tiga kategori yaitu: konstruktivis, platonis dan instrumentalis. Ide ini telah diadopsi dan digunakan secara luas (misalnya Ayebo \& Mrutu, 2019; Beswick, 2012; Muhtarom, Juniati, \& Siswono, 2017, 2019, 2020; Siswono et al., 2017). Beberapa penelitian mengungkapkan bahwa keyakinan mempengaruhi praktik pembelajaran yang dilaksanakan di kelas (Muhtarom, Juniati, \& Siswono, 2019, 2020). Namun demikian, faktanya seorang guru lebih percaya matematika sebagai alat, sedangkan dalam praktiknya, mereka meyakini kepada pandangan bahwa siswa harus melihat matematika sebagai aktivitas manusia (Siswono et al., 2017). Ini menunjukkan ketidaksesuaian antara konteks keyakinan dengan konteks di mana praktik pengajaran yang dilakukan.

Hasil penelitian di atas, menjadi landasan untuk meneliti keyakinan dan praktik pembelajaran mahasiswa calon guru matematika. Mahasiswa yang belum memiliki pengalaman mengajar di sekolah, tentunya tidak dapat menghindar dari kesulitan dalam praktik pembelajaran matematika ketika kelak menjadi guru matematika. Cara mengatasi kesulitan setiap orang berbeda bergantung pada adversity quotient (AQ) yang dimiliki oleh mahasiswa (Stolz, 2002). Mahasiswa climber akan berusaha menyelesaikan tantangan yang dihadapi dan selalu optimis bahwa kesulitan selalu menuntut seseorang untuk berkembang. Mahasiswa camper tidak mau mengambil resiko dan keluar dari zona aman, sehingga mereka selalu dalam kondisi statis. Sedangkan mahasiswa quitter mudah menyerah dan cenderung 
menolak adanya tantangan. Mahasiswa diprediksi tidak akan menerapkan pembelajaran yang menantang siswa karena meyakini bahwa pendekatan yang diajarkan dosen ketika belajar efektif untuk mengajar matematika dan dia cenderung menggunakan metode tersebut.

Penelitian Muhtarom, Siswono \& Juniati (2020) memberikan gambaran bahwa keyakinan mahasiswa climber berorientasi konstruktivis dan apa yang diyakini oleh mahasiswa climber diimplementasikan dalam praktik pembelajaran di kelas. Namun demikian, penelitian tersebut belum menguraikan keyakinan mahasiswa camper dan quitter, serta dampak dari keyakinan terhadap praktik pembelajaran matematika. Berdasarkan uraian tersebut, maka dalam penelitian ini akan diuraikan deskripsi keyakinan mahasiswa dan hubungan keyakinan dengan praktik pembelajaran matematika di kelas ditinjau dari perbedaan adversity quotient (AQ).

\section{METODE PENELITIAN}

Penelitian ini menggunakan metode penelitian kualitatif. Subjek penelitian adalah tiga mahasiswa $\mathrm{S} 1$ Pendidikan Matematika di Kota Semarang yang masing-masing memiliki AQ climber, AQ camper dan AQ quitter. Pemilihan subjek penelitian diawali dengan pemberian angket Adversity Response Profile dan kemudian dilakukan pengkategorian AQ sesuai Stoltz (2000). Subjek terpilih adalah mahasiswa yang telah menempuh mata kuliah perencanaan pembelajaran serta memiliki pengalaman microteaching.

Sebelum digunakan, semua instrumen penelitian telah divalidasi oleh tiga orang validator. Hasil validasi instrumen menunjukkan bahwa instrumen layak digunakan dan sangat valid. Wawancara semi-terstruktur dilakukan untuk meneliti keyakinan subjek dan lembar observasi praktik pembelajaran untuk implementasi keyakinan ketiga subjek dalam pembelajaran matematika di kelas. Wawancara dan observasi praktik pembelajaran dilakukan sebanyak dua kali untuk setiap subjek penelitian sehingga dapat dilakukan triangulasi waktu untuk mendapatkan data penelitian yang kredibel. Wawancara dilakukan dengan berpedoman pada protokol untuk mengeksplorasi keyakinan yang diungkapkan oleh Muhtarom, Siswono \& Juniati (2019; 2020). Sedangkan observasi praktik pembelajaran dilakukan ketika subjek mengikuti program praktik pengalaman lapangan di SMP N 6 Semarang. Ketiga subjek mengajar materi sistem persamaan linier dua variable (SPLDV) pada siswa di kelas VIII yang mempunyai kemampuan akademik sama. Subjek climber mengajar di kelas VIIIB, subjek camper mengajar di kelas VIIIC, dan subjek quiiter mengajar di kelas VIIIA. Kegiatan pembelajaran diobservasi dan direkam sehingga diperoleh data praktik pembelajaran matematika di kelas dari ketiga subjek penelitian

Video hasil wawancara dan video praktik pembelajaran matematika di kelas diputar berulang kali untuk meningkatkan ketekunan terhadap perolehan data penelitian. Kemudian rekaman video diubah kedalam bentuk transkrip dan diverifikasi oleh ketiga subjek sehingga kredibilitas data penelitian dapat dipertanggungjawabkan. Data diberi kode dan dianalisis untuk menggambarkan keyakinan dan implementasi keyakinan dalam praktik pembelajaran. Analisis data penelitian menggunakan tiga alur 
kegiatan yaitu reduksi data, penyajian data dan penarikan kesimpulan (Miles \& Huberman, 1992). Hasil dari analisis data penelitian diperoleh deskripsi keyakinan dan praktik pembelajaran matematika dari ketiga subjek penelitian.

\section{HASIL DAN PEMBAHASAN}

Subjek climber meyakini bahwa matematika berkembang. Ini sejalan dengan pendapat bahwa penelitian terus menerus dilakukan sehingga matematika selalu berubah dan tidak pernah statis (Ayebo \& Mrutu, 2019). Sedangkan Subjek camper dan quitter meyakini bahwa pengetahuan matematika tidak berkembang dari zaman dahulu sampai sekarang, matematika sudah ada dan ditemukan. Ini sejalan dengan pendapat Siswono, Kohar, \& Hartono (2017) yang menyatakan bahwa matematika ditemukan, bukan diciptakan. Subjek camper meyakini matematika merupakan ilmu yang statis yang terdiri dari struktur matematika yang saling berkaitan. Sedangkan subjek quitter meyakini matematika adalah ilmu yang digunakan menyelesaikan masalah matematika. Berikut ini adalah kutipan wawancara dengan subjek quitter.

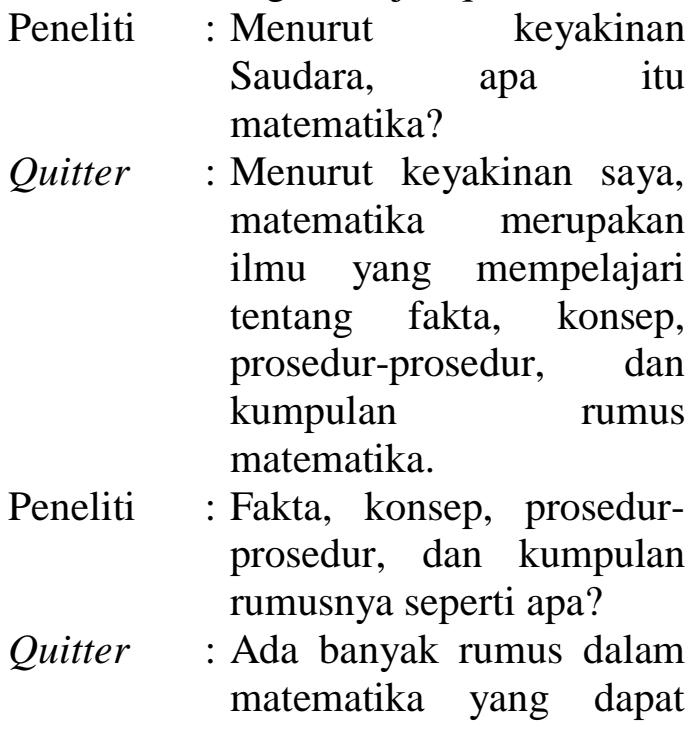

digunakan untuk menyelesaikan masalah matematika.

Peneliti : Apakah hanya masalah matematika saja?

Quitter : Iya.

Peneliti : Alasan Saudara meyakini?

Quitter : Dari pengalaman saya saat pertama mengenal matematika SD, SMP, SMA. Ada banyak rumusrumus yang saya terima ketika guru menjelaskan materi, sehingga dapat saya terapkan dalam menyelesaikan masalah matematika.

$\begin{array}{llr}\text { Peneliti } & \text { : Menurut } & \text { keyakinan } \\ & \begin{array}{l}\text { Saudara, apakah } \\ \text { matematika ditemukan }\end{array} \\ \text { Quitter } & \begin{array}{l}\text { atau diciptakan? } \\ \text { Matematika ditemukan } \\ \text { oleh para ahli. }\end{array}\end{array}$

Subjek climber meyakini bahwa pendekatan student center layak digunakan dalam pembelajaran matematika. Guru memberikan masalah, membimbing, dan siswa berdiskusi untuk menemukan konsep, rumus, serta penyelesaiannya. Ini sejalan dengan pendapat beberapa ahli bahwa pembelajaran dimulai dengan memberikan masalah kepada siswa (Muhtarom, Juniati, \& Siswono, 2019), membimbing siswa, berdiskusi untuk mengeksplorasi pengetahuan dan menemukan penyelesaian, mempresentasikan dan memberikan penguatan terhadap pekerjaan siswa (Danoebroto, Suyata, \& Jailani, 2020). Pendekatan ini menjadikan pembelajar sebagai fokus daripada konten matematika (Beswick, 2012). Subjek camper dan quitter meyakini bahwa pendekatan teacher center layak digunakan dalam pembelajaran matematika. Namun jika 
ditelaah lebih lanjut terkait dengan peran guru dan siswa ternyata menunjukkan perbedaan. Subjek camper meyakini guru berperan mentransfer pengetahuan melalui penjelasan materi sehingga siswa benarbenar paham. Pengajaran matematika berfokus pada konten materi tetapi juga menekankan pemahaman aktif (Beswick, 2012; Muhtarom, Juniati \& Siswono, 2017). Berikut ini adalah kutipan wawancara dengan subjek camper.

Peneliti : Pendekatan pembelajarannya seperti apa?

Camper : Teacher center. Saya lebih setuju teacher center karena guru lebih berpengalaman sehingga dapat mengajarkan konsep secara benar, kemudian bahasa lisan dan tulisan buku berbeda, dan saya meyakini siswa lebih mudah memahami bahasa lisan guru; karena saya mengalaminya sampai sekarang. Saya masih kesulitan untuk menerjemahkan bahasa buku kalau tidak mencari referensi-referensi lain.

Peneliti : Peran guru seperti apa?

Camper : Mentransfer ilmu secara langsung yaitu menerangkan konsep secara langsung kepada siswa, guru membimbing, memberikan pemahaman pengetahuan kepada siswa selama proses pengajaran, menekankan pada pemahaman konsep, ide, dan prosedur matematika, dan mengarahkan siswa agar mengerjakan soal.
Maksud membimbing itu seperti ketika ada siswa yang salah, kita tunjukkan letak kesalahannya dan kita luruskan dengan memberikan prosedur atau solusinya. Belajar matematika harus kondusif, guru harus mampu mengontrol kelas.

Peneliti : Peran siswa seperti apa?

Camper : Siswa mendengarkan, belajar mengerjakan soal seperti yang di contohkan oleh guru, atau bahkan mengerjakan dengan caranya sendiri asalkan prosedurnya benar itu tidak apa-apa.

Sedangkan subjek quitter meyakini bahwa guru mentransfer keterampilan, pengetahuan kepada siswa. Guru memegang kendali dalam proses pembelajaran dan mempertahankan konteks sosial di mana kesalahan harus dihindari. Peran siswa adalah mendengarkan, merespon pertanyaan guru, dan mengerjakan latihan soal dengan menggunakan prosedur yang telah dicontohkan guru. Pandangan ini diperkuat oleh Muhtarom, Juniati, \& Siswono (2017) yang menyatakan bahwa guru mengkomunikasikan pengetahuan dengan cara yang jelas dan terstruktur, menjelaskan solusi yang benar, memberi siswa masalah yang jelas dan dapat dipecahkan, dan memastikan ketenangan kelas. Pengajaran matematika melatihkan kemampuan mekanistik berhitung kepada siswa (Purnomo, Suryadi, \& Darwish, 2016), pengajaran matematika berfokus pada konten materi, dengan penekanan pada kinerja (Beswick, 2012). Berikut ini 
adalah kutipan wawancara dengan subjek quitter.

\begin{tabular}{|c|c|}
\hline Peneliti & $\begin{array}{l}\text { Saudara } \\
\text { pendekatan seperti apa } \\
\text { yang cocok untuk } \\
\text { diterapkan? }\end{array}$ \\
\hline Quitter & $\begin{array}{l}\text { Teacher center, karena } \\
\text { guru berperan secara } \\
\text { langsung dalam kegiatan } \\
\text { pembelajaran di kelas. } \\
\text { Semua informasi berpusat } \\
\text { pada guru. Guru } \\
\text { mentransfer pengetahuan } \\
\text { yang dimilikinya kepada } \\
\text { siswa. }\end{array}$ \\
\hline Peneliti & Peran guru seperti apa? \\
\hline Quitter & $\begin{array}{l}\text { Karena guru telah } \\
\text { mempelajari materi } \\
\text { terlebih dahulu, jadi guru } \\
\text { telah memahami materi } \\
\text { untuk disampaikan kepada } \\
\text { siswa. Guru dapat } \\
\text { mentransfer } \\
\text { langsung apa yang } \\
\text { dimilikinya kepada siswa, } \\
\text { seperti keterampilan, } \\
\text { pengetahuan. }\end{array}$ \\
\hline Peneliti & : Peran siswa? \\
\hline Quitter & $\begin{array}{l}\text { Siswa mendengarkan apa } \\
\text { yang dijelaskan guru, } \\
\text { menerapkan rumus-rumus } \\
\text { untuk menyelesaikan soal } \\
\text { saat pembelajaran. }\end{array}$ \\
\hline
\end{tabular}

Perbedaan juga ditunjukkan dalam pemilihan soal matematika. Subjek camper meyakini bahwa siswa terlebih dahulu diberikan soal-soal rutin untuk melatih keterampilannya sehingga mengerti pola jawaban. Jika sudah terampil, maka soal non-rutin diberikan kepada siswa dalam pembelajaran matematika. Sedangkan subjek climber memberi soal non-rutin dalam pembelajaran matematika. Subjek climber menyediakan berbagai alternatif pengalaman belajar siswa, memastikan kebebasan siswa mengekspresikan ideidenya ketika membuat soal matematika (Muhtarom, Siswono, \& Juniati, 2020). Berikut ini adalah kutipan wawancara dengan subjek climber.

Peneliti : Soal yang berikan ke siswa berupa soal rutin atau soal non-rutin? Alasannya?

Climber : Soal non-rutin. Soal nonrutin tidak langsung diketahui cara penyelesaiannya, tapi kalau soal rutin dapat lihat menggunakan cara apa. Kalau menggunakan soal non-rutin siswa akan lebih berpikir bagaimana cara mengerjakan soalnya dan berbagai macam cara dapat mengerjakan soalnya.

Peneliti : Apakah siswa diberi kebebasan?

Climber : Siswa diberikan kebebasan menyelesaikan dengan caranya sendiri, tidak harus sama dengan cara yang diajarkan guru yaitu ini rumusnya, caranya seperti ini. Siswa mengerjakan sesuai dengan pemikirannya, siswa boleh menggunakan berbagai macam cara.

Peneliti : Siapa yang harus membuat soal tersebut?

Climber : Guru dan siswa ikut serta membuat soal matematika. Guru membuat soal tetapi siswa juga diajarkan untuk membuat soal matematika juga. Jadi guru dapat mengetahui seberapa paham siswanya ketika membuat dan menyelesaikan soal yang telah dibuatnya. 
Lebih lanjut subjek quitter meyakini pemberian soal rutin yang dibuat oleh guru, maka siswa akan terampil dan terbiasa dalam menyelesaikan soal yang sejenis. Pendapat ini didukung oleh Tamba, Cendana, \& Pratiwi (2021) yang menyatakan bahwa keyakinan instrumentalis dikaitkan dengan pekerjaan individu siswa, latihan pertanyaan rutin, dan ketergantungan pada buku teks atau lembar kerja. Muhtarom, Juniati, \& Siswono (2017) menyatakan bahwa mahasiswa yang memiliki keyakinan instrumentalis memandang soal dalam pengajaran matematika sebagai soal rutin yang hanya memiliki satu cara penyelesaian, menekankan kinerja urutan langkah dan berorientasi pada jawaban yang benar. Berikut ini adalah kutipan wawancara dengan subjek quitter.

Peneliti : Soal yang diberikan berupa soal rutin atau soal non-rutin? Alasannya!

Quitter : Saya memberikan soal rutin, karena soal rutin merupakan soal yang biasa dikerjakan oleh siswa. Ketika siswa menghadapi permasalahan yang dihadapi, siswa langsung 'tahu' prosedur yang akan dikerjakan. Siswa tidak merasa kesulitan karena sudah terbiasa.

Peneliti : Apakah soal latihan dan contoh soal merupakan soal yang mirip?

Quitter : Soalnya mirip sehingga siswa lebih mudah memahaminya karena telah mendapatkan pengetahuan dari contoh soal, sebelum ke latihan soal.
Peneliti : Siapa yang membuat soal tersebut?
Quitter : Yang membuat soal adalah guru dari buku yang dimiliki siswa.

Subjek climber memotivasi siswa dengan memberikan soal yang menantang, berawal dari yang memiliki tingkat kesulitan mudah ke susah (bertahap). Subjek camper dan quiter memberikan penghargaan terhadap hasil pekerjaan siswa untuk memotivasi. Guru tradisional menempatkan pengendalian belajar siswa akan terkait strategi memotivasi dengan memberikan pujian, penghargaan, ataupun hukuman (Liviananda \& Ekawati, 2019). Tetapi guru yang berkeyakinan konstruktivis memotivasi didasarkan pada substansial kualitas seperti termuatnya tantangan dari soal matematika (Muhtarom, Siswono, \& Juniati, 2020).

Terkait dengan perbedaan keyakinan tentang belajar matematika, subjek climber meyakini siswa mengkonstruksi konsep matematika, mengembangkannya sehingga dapat menyelesaikan soal matematika bervariasi. Ini sejalan dengan ide konstruktivis bahwa belajar adalah aktivitas untuk memperoleh keterampilan dalam penalaran dan membangun hal baru sebagai eksplorasi otonom (Beswick, 2012). Subjek camper meyakini bahwa siswa harus memahami konsep yang diajarkan guru dan keterampilan menghitung untuk menyelesaikan soal matematika. Ini sejalan dengan ide Platonis bahwa belajar adalah aktivitas memahami konsep belajar dan konstruksi aturan tidak ditekankan. Sedangkan subjek quitter meyakini bahwa yang harus dikuasai siswa dalam belajar matematika adalah keterampilan 
berhitung dalam menyelesaikan soal matematika. Ini sejalan dengan ide instrumentalis bahwa belajar merupakan aktivitas mengerjakan soal dengan menggunakan prosedur yang telah dicontohkan (Tamba, Cendana, \& Pratiwi, 2021).

Praktik pembelajaran subjek camper berorientasi platonis. Keyakinan subjek camper tentang pendekatan pembelajaran teacher center diimplementasikan melalui tahapan kegiatan praktik pembelajaran yaitu mengajarkan konsep, memberikan contoh soal, membimbing siswa, memberikan soal latihan yang kompleks, mengevaluasi, dan mempresentasikan hasilnya. Pembelajaran dilakukan melalui metode ceramah, metode tanya jawab dan diskusi. Peran guru adalah explainer yaitu memberikan pemahaman konseptual dengan pengetahuan yang terpadu kepada siswa selama proses pengajaran, menekankan pada pemahaman konsep, ide, dan prosedur matematika. Berikut adalah kutipan praktik pembelajaran subjek camper.

Camper : Ibu tekankan lagi perbedaan PLSV dengan PLDV. PLSV memuat satu variabel dengan pangkat variabelnya satu, sedangkan PLDV memuat dua variabel dengan pangkat variabelnya satu. Bentuk umum SPLDV?

Siswa $\quad: a_{1} x+b_{1} y=c_{1} ;$ dan $a_{2} x+$ $\mathrm{b}_{2} \mathrm{y}=\mathrm{c}_{2}$

Camper : Ingat langkah-langkah penyelesaian SPLDV menggunakan metode substitusi yaitu: 1) lihat koefisien dari variabel yang dipilih untuk diubah bentuknya, 2) pilih koefisien terkecil maka akan didapat nilai variabel yang masih mengandung variabel lain (bentuk $\mathrm{x}$ dalam y atau $\mathrm{y}$ dalam x), 3) Substitusikan persamaan tersebut ke persamaan lain, dan 4) ketika sudah didapat nilai variabel lain yang tidak mengandung variabel maka nilai tersebut disubtitusikan ke nilai variabel yang masih mengandung variabel lain sehingga akan didapat nilai dari kedua variabel.

Subjek matematika camper memberikan contoh soal dan latihan soal dengan tipe soal yang berbeda. Soal diberikan dari yang mudah terlebih dahulu, kemudian bertingkat menjadi soal sulit untuk membangun pemahaman siswa. Ini ditunjukkan dari pemberian soal latihan berupa soal rutin yang setipe dengan contoh soal yang diberikan guru. Soal latihan juga memuat soal non rutin yang berbeda dengan apa yang diajarkan oleh guru. Berikut adalah kutipan praktik pembelajaran subjek camper.

Camper : .... menyelesaikan SPLDV dengan metode substitusi.

Lihat $2 \mathrm{x}+3 \mathrm{y}=6$ (persamaan satu), dan $\mathrm{x}+\mathrm{y}$ $=2$ (persamaan dua).

Perhatikan persamaan satu, kita mencari variabel $\mathrm{x}$ atau y terlebih dahulu

$2 x+3 y=6 \quad$ (kedua ruas dikurangi dengan $3 y$ )

$2 \mathrm{x}=-3 \mathrm{y}+6$ (kedua ruas dibagi 2)

$\mathrm{x}=\frac{-3 \mathrm{y}+6}{2}$

Kita sudah mendapatkan persamaan dari $\mathrm{x}$. Ingat $\mathrm{x}$ jangan dikembalikan ke persamaan awal yaitu 
DOI: https://doi.org/10.24127/ajpm.v10i1.3477

persamaan satu. Kita substitusikan ke persamaan kedua.

$\mathrm{x}+\mathrm{y}=2$

$\frac{-3 y+6}{2}+y=2$

Nilai
substitusikan $\frac{-3 y+6}{2}=\frac{-3(2)+6}{2}=0$

Camper : Ibu mempunyai soal latihan, silahkan dikerjakan secara berkelompok.

1. Harga satu baju dan tiga kaos Rp. 185.000,00 dan harga tiga baju dan tiga kaos untuk jenis yang sama Rp. 275.000,00. Berapa harga dua baju dan satu kaos?

2. Nadia membuat sebuah cerita yang dinyatakan oleh sistem persamaan berikut: $5 \mathrm{p}+2 \mathrm{k}=$ 15 , dan $4 p+8 k=20$. Berapa nilai $\mathrm{p}$ dan $\mathrm{k}$ ?

Subjek camper membantu siswa yang mengalami kesulitan dengan menjelaskan lebih detail materi matematika supaya siswa paham. Peran siswa adalah mendengarkan, mengikuti dan mengembangkan apa yang diajarkan guru yaitu melalui penerapan konsep matematika dalam kehidupan sehari-hari. Berikut adalah contoh bantuan yang diberikan kepada siswa.

Camper : (membimbing siswa). Harga satu baju dan tiga kaos sebesar 185.000, kemudian harga 3 baju dan 3 kaos seharga 275.000, ditanyakan harga 2 baju dan 1 kaos. Untuk menyelesaikan soal cerita harus dimisalkan terlebih dahulu.

Siswa : Misalkannya seperti apa?

Camper : Kamu misalkan $\mathrm{x}$ dan $\mathrm{y}$, gunakan s dan c juga tidak apa-apa. Dimisalkan dulu harga 1 kaos .... dan harga 1 baju .... (siswa: $x$ dan $y$ ).

Siswa : (siswa mulai mengerjakan)

Camper : (membimbing siswa) Ini ditambahkan harga satu baju dimisalkan $\mathrm{x}$ dan harga satu kaos dimisalkan y. Yang kita cari harganya, bukan bajunya. Ini diganti, yang benar $3 x+3 y=275.000$, silahkan ditulis dulu.

Siswa : Iya Bu.

Camper : (membimbing siswa) Soal cerita harus diubah menjadi model matematika, kita misalkan menggunakan variabel $\mathrm{x}$ dan $\mathrm{y}$. Variabel $\mathrm{x}$ untuk memisalkan harga satu baju dan variabel y untuk memisalkan harga satu kaos. Berarti $\mathrm{x}=$ harga 1 baju, dan $\mathrm{y}=$ harga 1 kaos. Coba ditulis (siswa menulis di buku).

Siswa : Bu, kalau mencari harga kaos seperti ini tidak?

Camper : 'Ini' ditambah 'ini' tidak bisa (menunjuk buku siswa). Berarti $3 \mathrm{k}=275.000-3 \mathrm{~b}$. Untuk mencari nilai $b$, kita masukkan nilai $k$ ke persamaan lainnya.

Praktik pembelajaran subjek quitter berorientasi instrumentalis. Subjek quitter menggunakan metode ceramah untuk menjelaskan materi dan contoh soal materi penyelesaian eliminasi dan substitusi sehingga terjadi transfer pengetahuan. Peran guru 
mendampingi siswa mengerjakan latihan soal. Selama proses pembelajaran, subjek quitter memegang kendali dalam proses pembelajaran dan menekankan kesalahan adalah sesuatu yang harus dihindari. Berikut adalah kutipan praktik pembelajaran subjek quitter.

Quitter : Perhatikan semua!. Penanya diletakkan di atas meja dan semua memperhatikan ke depan. Ini contoh sistem persamaan linier dua variabel yang memuat dua persamaan linier dua variabel. Persamaan pertama $(3 \mathrm{x}-\mathrm{y}=4)$ koefisiennya apa?

Siswa : Koefisien $\mathrm{x}=3$ dan koefisien $\mathrm{y}=-1$.

Quitter : Kalau Persamaan kedua (3x $+\mathrm{y}=2)$ koefisiennya apa?

Siswa : Koefisien $\mathrm{x}=3$ dan koefisien $\mathrm{y}=1$.

Quitter : Selanjutnya kita belajar metode substitusi. Substitusi artinya mengganti suatu sebuah variabel dengan menggunakan persamaan yang lain. Langkahlangkahnya adalah sebagai berikut: 1) menyatakan variabel dalam variabel lain, misal menyatakan x dalam y atau sebaliknya. 2) Mensubstitusikan persamaan yang sudah kita ubah pada persamaan yang lain, dan 3) mensubstitusikan nilai yang sudah ditemukan dari variabel $\mathrm{x}$ atau $\mathrm{y}$ ke salah satu persamaan.

Nyatakan $\mathrm{x}$ dalam y atau sebaliknya. Di sini kita merubah persamaan pertama $2 \mathrm{x}+\mathrm{y}=3$ menjadi $\mathrm{y}=3-$
$2 \mathrm{x}$ dengan cara kedua ruas dikurangi $2 \mathrm{x}$.

Selanjutnya kita substitusikan $\mathrm{y}=3-2 \mathrm{x}$ ke persamaan yang lain.

$\mathrm{x}-3 \mathrm{y}=5$

$\mathrm{x}-3(3-2 \mathrm{x})=5$

$\mathrm{x}-9+6 \mathrm{x}=5$

$7 \mathrm{x}-9=5$

$7 \mathrm{x}=5+9 \Rightarrow \mathrm{x}=2$.

Subjek quitter memberikan contoh soal dan latihan soal dengan tipe soal yang tidak berbeda. Soal yang diberikan dalam kegiatan pembelajaran merupakan soal rutin yang dibuat oleh guru supaya siswa terampil dan terbiasa dalam menyelesaikan soal yang sejenis. Dapat dikatakan demikian karena siswa telah memiliki pengetahuan untuk menyelesaikan soal latihan berdasarkan langkah penyelesaian contoh soal yang diajarkan oleh guru. Keyakinan instrumentalis dikaitkan dengan pekerjaan individu siswa, latihan pertanyaan rutin, dan ketergantungan pada buku teks atau lembar kerja (Siswono et al., 2017 dan Tamba, Cendana, \& Pratiwi, 2021). Muhtarom, Juniati, \& Siswono (2017) menyatakan bahwa mahasiswa yang memiliki keyakinan instrumentalis memandang soal dalam pengajaran matematika sebagai soal rutin yang hanya memiliki satu cara penyelesaian, menekankan kinerja urutan langkah, dan berorientasi pada jawaban yang benar. Berikut adalah kutipan praktik pembelajaran subjek quitter.

Quitter : Selanjutnya kita belajar materi penyelesaian SPLDV dengan metode eliminasi.

Dari sistem persamaan linier dua variabel berikut: $2 \mathrm{x}+$ $2 \mathrm{y}=14.000$, dan $\mathrm{x}+3 \mathrm{y}=$ 15.000. Tentukan nilai $x$ dan y dengan metode eliminasi. 
DOI: https://doi.org/10.24127/ajpm.v10i1.3477

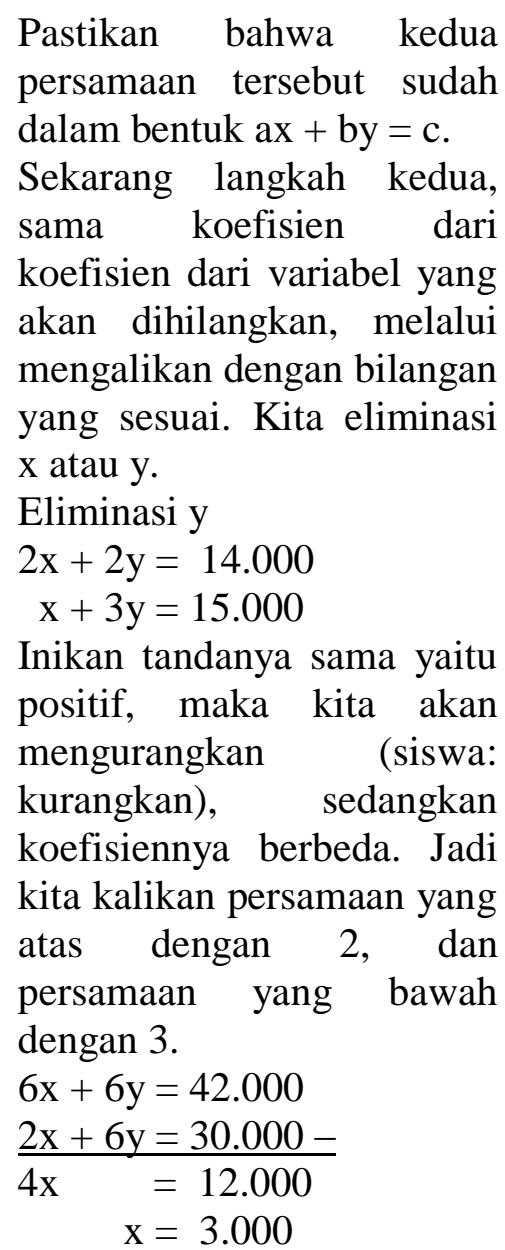

Eliminasi $\mathrm{x}$

$$
\begin{aligned}
2 x+2 y & =14.000 \\
2 x+6 y & =30.000- \\
\hline-4 y & =-16.000 \\
y & =4.000
\end{aligned}
$$

Quitter : Ibu membagi kalian menjadi beberapa kelompok, dengan masing-masing kelompok terdiri dari 5-6 siswa. Ini sudah sesuai dengan kelompoknya. Selesaikan soal berikut ini.
1. Tentukan himpunan penyelesaian dari sistem persamaan $\mathrm{x}+\mathrm{y}=5$ dan $\mathrm{x}-2 \mathrm{y}=2$.

2. Tentukan himpunan penyelesaian dari sistem persamaan linier dua variabel berikut ini.
a. $3 x-y=4$
$3 x+y=2$
b. $x+2 y=7$
$x-2 y=-5$

Sejalan dengan keyakinannya, peran siswa adalah mendengarkan dan mengerjakan latihan soal dengan menggunakan prosedur yang telah dicontohkan guru. Siswa belajar matematika dengan memahami konsep materi yang diajarkan dan terampil berhitung untuk menyelesaikan soal sesuai dengan cara yang diajarkan oleh guru. Ini sejalan dengan pendapat Beswick (2012) yang menjelaskan bahwa belajar matematika dipandang sebagai penerimaan pasif pengetahuan dan penerapan keahlian. Jika ada siswa yang mengalami kesulitan, subjek quitter membantu siswa yang mengalami kesulitan dengan menjelaskan lebih detail materi matematika supaya siswa paham. Berikut adalah contoh bantuan yang diberikan kepada siswa.

Quitter : Perhatikan semuanya. Untuk cara mengerjakannya lihat buku paket.

(guru berkeliling membimbing siswa) Ini caranya sama dengan yang ada dibuku. Kalian kerjakan sesuai perintah sesuai dengan contoh yang sudah dijelaskan dan dibuku. Ini mencari variabel $x$. Sama tidak koefisiennya? Jika sudah sama tinggal dikurangkan saja.

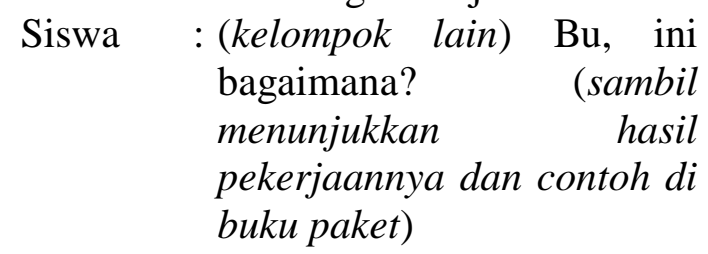


Quitter : Ini sudah didapatkan nilai y $=2$, selanjutnya mencari nilai variabel $\mathrm{x}$.

Tulis persamaannya $\mathrm{x}+\mathrm{y}=$ 5 dan $\mathrm{x}-2 \mathrm{y}=2$. Pertama hendak mengeliminasi variabel yang mana? (siswa: variabel $\mathrm{x}$ ). Ini kan tandanya positif semua, maka tandanya berupa pengurangan. Untuk y - (2y) sama dengan? (siswa: $3 y)$. Benar $3 y$. Jadi $y=1$.

Uraian di atas menunjukkan adanya hubungan yang konsisten antara keyakinan dan praktik pengajarannya. Mahasiswa yang memiliki AQ quitter memandang matematika sebagai kumpulan aturan dan rumus, maka dalam pembelajaran lebih menekankan demonstrasi aturan dan rumus. Mahasiswa quitter kurang memberikan kesempatan eksplorasi kepada siswa dan mempertahankan konteks sosial, jadi kesalahan harus dihindari. Sementara mahasiswa yang memiliki AQ camper yang memiliki keyakinan bahwa matematika memuat topik yang saling berelasi secara logis, dalam praktik pembelajaran lebih menekankan pada pemahaman dan hubungan konsep materi. Sedangkan mahasiswa yang memiliki AQ climber berkeyakinan konstruktivis, menekankan aktivitas siswa dalam proses menyusun matematika.

Hasil penelitian ini menunjukkan bahwa keyakinan yang berbeda mengakibatkan berbedanya praktik pembelajaran matematika di dalam kelas. Ini sejalan dengan beberapa peneliti yang menjelaskan bahwa keyakinan memengaruhi praktik pembelajaran yang dilaksanakan di kelas (Beswick, 2012; Muhtarom, Juniati, Siswono, 2019). Mahasiswa climber memiliki pengetahuan yang diperlukan untuk mengajar matematika dengan pendekatan berpusat pada siswa, misalnya memahami teori belajar yang relevan, memahami karakteristik siswa dan memahami konten materi matematika yang akan disampaikan. AQ memberikan dampak pada keyakinan seseorang, kemudian keyakinan berdampak pada perubahan praktik pembelajaran. Sementara mahasiswa camper tidak mau mengambil resiko dan keluar dari zona aman, sehingga mereka selalu dalam kondisi statis. Mahasiswa camper yang berkeyakinan bahwa matematika merupakan ilmu statis, maka pengajaran matematika menekankan pemahaman siswa. Mahasiswa camper menjelaskan materi, memberikan tugas, memantau siswa bekerja, memberikan umpan balik wa, melakukan pencegahan yang menghambat praktik pembelajaran. Sedangkan mahasiswa quitter adalah seseorang yang mudah menyerah dan cenderung menolak adanya tantangan. Mahasiswa quitter melihat bahwa pembelajaran berpusat pada guru efektif untuk mengajar matematika dan cenderung menggunakan metode ceramah dalam praktik pembelajaran

\section{KESIMPULAN DAN SARAN}

Hasil penelitian menunjukkan bahwa ketiga mahasiswa calon guru matematika yang memiliki AQ climber, camper, dan quitter memiliki keyakinan yang berbeda. Mahasiswa calon guru climber meyakini bahwa matematika adalah sebagai cabang ilmu yang dinamis. Mahasiswa calon guru camper meyakini bahwa matematika merupakan ilmu yang statis tetapi terpadu, terdiri dari struktur matematika yang saling terkait. Sedangkan mahasiswa calon guru quitter meyakini bahwa matematika sebagai alat yang digunakan 
untuk menyelesaikan masalah matematika. Terdapat hubungan yang konsisten antara keyakinan dan praktik pengajaran dari ketiga mahasiswa. Keyakinan ketiga mahasiswa diimplementasikan dalam berbagai tindakan praktik pembelajaran untuk memahamkan pengetahuan baru kepada siswa selama proses pembelajaran matematika. Keyakinan dan praktik berpengaruh satu sama lain dan berkembang bersama. Selanjutnya, menarik untuk dilakukan penelitian keyakinan mahasiswa terkait literasi dan penggunaan ICT dalam pembelajaran.

Adapun saran untuk penelitian selanjutnya, yaitu memperluas analisis perbedaan keyakinan mahasiswa ditinjau dari hal lain untuk bisa menganalisis mahasiswa secara menyeluruh.

\section{DAFTAR PUSTAKA}

Ayebo, A., \& Mrutu, A. (2019). An exploration of calculus students' beliefs about Mathematics. International Electronic Journal of Mathematics Education, 14(2), 385-392. https://doi.org/10.29333/iejme/5 728

Belbase, S. (2019). Meanings, dimensions, and categories of mathematics teacher beliefs: A navigation through the literature. International Journal on Emerging Mathematics Education, 3(1), 1-26.

Beswick, K. (2012). Teachers' beliefs about school mathematics and mathematicians' mathematics and their relationship to practice. Educational Studies in Mathematics, 79(1), 127-147

Danoebroto, S. W., Suyata, S., \& Jailani, J. (2020). Teacher's belief of mathematical literacy based on local culture: Case study of junior high school mathematics teacher. In Journal of Physics: Conference Series (Vol. 1567, No. 3, p. 032008). IOP Publishing. Retrieved from https://iopscience.iop.org/article/ $10.1088 / 1742-$ 6596/1567/3/032008/meta

Kemendiknas. (2007) Permendiknas No. 16 tahun 2007 tentang standar kualifikasi akademik dan kompetensi guru. Jakarta: Kemendiknas.

Liviananda, F., \& Ekawati, R. (2019). Hubungan keyakinan siswa tentang matematika dan pembelajarannya dengan kemampuan matematika. MATHEdunesa, 8(2), 357-364.

Miles, M., \& Huberman, A. M. (1992). Analisis data kualitatif: buku sumber tantang metode-metode baru. Jakarta: UI Press.

Muhtarom, Juniati, D., \& Siswono, T. Y. E. (2017). Consistency and inconsistency of prospective teachers' beliefs in mathematics, teaching, learning and problem solving. In AIP Conference Proceedings (Vol. 1868, No. 1, p. 050014). AIP Publishing.

Muhtarom, M., Juniati, D., \& Siswono, T. Y. E. (2017). Pengembangan angket keyakinan terhadap pemecahan masalah dan pembelajaran matematika. Jurnal Ilmiah Pendidikan Matematika, 2(1), 55-64.

Muhtarom, M., Juniati, D., \& Siswono, T. Y. E. (2019). Examining prospective teacher beliefs and pedagogical content knowledge towards teaching practice in mathematics class: A case study. Journal on Mathematics 
DOI: https://doi.org/10.24127/ajpm.v10i1.3477

Education, 10(2), 185-202. https://doi.org/10.22342/jme.10. 2.7326.185-202.

Muhtarom, Juniati, D., Siswono, T. Y. E., \& Rahmatika, I. (2018). Teachers' and Students' beliefs of mathematics at state Senior High School 5 Semarang. Jurnal Riset Pendidikan Matematika, 5(1), 65-72.

Muhtarom, M., Siswono, T. Y. E., \& Juniati, D. (2020). Climber prospective teacher: relationship beliefs and mathematics teaching practice. Al-Jabar: Jurnal Pendidikan Matematika, 11(1), 83-92.

Purnomo, Y. W., Suryadi, D., \& Darwish, S. (2016). Examining pre-service elementary school teacher beliefs and instructional practices in mathematics class. International Electronic Journal of Elementary Education, 8(4), 629-642. Retrieved from https://www.iejee.com/index.ph p/IEJEE/article/view/137

Siswono, T. Y. E., Kohar, A. W., \& Hartono, S. (2017). Secondary teachers' mathematics-related beliefs and knowledge about mathematical problem-solving. Journal of Physics: Conference Series (Vol. 812, p. 012046). IOP Publishing. Retrieved from http://iopscience.iop.org/article/1 $0.1088 / 1742$ 6596/812/1/012046/meta

Siswono, T. Y. E., Kohar, A. W., Hartono, S., Rosyidi, A. H., Kurniasari, I., \& Karim, K. (2019). Examining teacher mathematics-related beliefs and problem-solving knowledge for teaching: Evidence from Indonesian primary and secondary

teachers. International

Electronic Journal of

Elementary Education, 11(5), 493-506. Retrieved from https://www.iejee.com/index.ph p/IEJEE/article/view/789

Siswono, T. Y. E., Kohar, A. W., Rosyidi, A. H., \& Hartono, S. (2017). Primary school teachers' beliefs and knowledge about mathematical problem-solving and their performance on problem-solving task. World Trans. on Engng. and Technol. Educ, 15(2), 126-131.

Stoltz, P. G. (2000). Adversity Quotient: turning obstacles into opportunities (Mengubah hambatan menjadi peluang). Terjemahan oleh: $\mathrm{T}$. Hermaya. Jakarta: PT. Gramedia Widiasarana Indonesia.

Tamba, K. P., Cendana, W., \& Pratiwi, J. (2021). Keyakinan Epistemologis dan BelajarMengajar Matematika Calon Guru Matematika Sekolah Dasar. Jurnal Basicedu, 5(1), 65-76. 